\title{
Rancang Bangun Aplikasi Pembelajaran Rambu-Rambu Lalu Lintas Berbasis Android Untuk Siswa Sekolah Dasar
}

\author{
Muhammad Ali Syakur, Devie Rosa Anamisa \\ Universitas Trunojoyo Madura
}

\begin{abstract}
Abstrak
Optimalisasi kualitas sekolah tergantung pada pemahaman untuk proses belajar mengajar di dalam kelas maupun di luar kelas. sekolah berkualitas menunjukkan kapasitas kemampuan siswa dalam mengotpimalkan program tertentu seperti dalam pembelajaran berlalu lintas. Pelajaran ini difokuskan pada pengamatan mengajar berupa pengenalan kesadaran berlalu lintas. Proses belajar dengan menggunakan pendekatan kualitatif,seperti grounded theory berbasis android belum pernah diperkenalkan pada siswa-siswi sekolah dasar (SD). Pendekatan ini dilakukan dengan tujuan mengenalkan perangkat pembelajaran menjadi solusi baru dalam perkembangan dunia pendidikan sebagai pembelajaran interaktif. Selain itu, penanaman kesadaran berlalu lintas sebaiknya dilakukan sejak dini. Masa anak-anak merupakan fase awal dalam kehidupan manusia untuk memulai sosialisasi eksternal di luar lingkungan keluarga intinya dan pada fase ini anak-anak cenderung lebih mudah untuk menyerap nilai-nilai termasuk pengetahuan berlalu lintas karena pada nantinya akan selalu berinteraksi dengan sistem lalu lintas dan jalan raya dalam menjalankan aktivitasnya. Dengan keterbatasan-keterbatasan tersebut maka khususnya siswa-siswi Kelas II SD sangat membutuhkan metode pembelajaran ini untuk mengenalkan rambu-rambu lalu lintas, khususnya rambu peringatan, larangan, perintah dan petunjuk berbasis android sebagai pembelajaran interaktif, dengan harapan agar dapat memotivasi siswa-siswi dalam membantu belajar memahami dan mengerti konsep-konsep rambu rambu lalu lintas tanpa harus membawa buku dan pengajaran menjadi lebih menarik sehingga dapat memotivasi belajar siswa-siswi SD baik di sekolah maupun diluar sekolah. Selain itu, aplikasi ini juga dapat membantu sekolah menjadi SD yang berkualitas dengan menyiapkan generasi penerus bangsa yang berkualitas sadar akan hukum berlalu lintas.
\end{abstract}

Kata kunci: Metode Grounded Theory, Pembelajaran Interaktif, Rambu-Rambu Lalu Lintas, Sekolah Dasar, Android

\section{PENDAHULUAN}

Sekolah merupakan sebuah living systems yaitu sistem-sistem yang fundamental dalam melayani siswa. Oleh karena itu siswa merupakan aspek penting yang patut diperhatikan dalam upaya peningkatan kualitas sekolah, bayangkan saja sekolah yang bagus, guru yang berkualitas, fasilitas yang lengkap namun tidak ada satu siswa pun yang berkualitas maka sekolah itu hanyalah sebuah bangunan tempat berkumpulnya para guru dan pengurus sekolah. Untuk itulah, peningkatan kualitas sekolah tidak hanya fokus pada sarana dan prasarana sekolah, namun juga pada pemahaman bagaimana pembelajaran siswa (Iwan, 2010). Belajar memahami pembelajaran siswa merupakan salah satu proses agar sekolah dapat mengkoreksi diri dan bersifat objektif serta tidak memproteksi diri dan mengklaim sebagai sekolah terbaik versi sekolah itu sendiri (Arif, 2014).
Sekolah Dasar (SD) sebagai salah satu jenjang pendidikan di Indonesia mempunyai peranan penting dalam memberikan pengajaran kepada anak didik yang masih dalam kategori dini yaitu antara umur 7 - 12 tahun (Marthya, 2010). Pembelajaran yang dilakukan di SD meliputi berbagai hal yang semua terangkum dalam mata pelajaran yang diberikan serta ketrampilan atau pengetahuan lain. Beberapa mata pelajaran dikenal sebagai mata pelajaran tematik pada kelas II SD antara lain pembelajaran pengenalan rambu-rambu lalu lintas. Pembelajaran pengenalan rambu-rambu lalu lintas merupakan mata pelajaran yang dapat membantu siswa-siswi SD, khususnya kelas II untuk membiasakan belajar melihat rambu-rambu lalu lintas. Jika mereka melihat rambu - rambu itu di jalan, maka mereka langsung mempraktekkannya sebagai bentuk kesadaran berlalu lintas di jalan. Proses perkembangan individu khususnya anak- 
anak merupakan sebuah proses yang unik yang berbeda dengan proses perkembangan orang dewasa. Usia anak-anak (7 - 12 tahun) memiliki struktur perkembangan kognitif yang berbeda dengan usia sebelumnya atau sesudahnya (Kusbianto, 2013) Pada usia ini anak-anak memahami sesuatu lebih cepat dengan suatu yang kongrit, bukan abstrak. Mereka juga telah mampu memahami konservasi. Sehingga untuk membantu siswa-siswi SD dalam memahami rambu-rambu lalu lintas diperlukan seorang pengajar untuk menggunakan sesuatu yang kongkrit dalam menjelaskan konsep-konsep tersebut, khususnya rambu-rambu peringatan, larangan, perintah dan petunjuk. Dukungan lingkungan khususnya orang tua, dan pengajar serta fasilitas merupakan faktor penting dalam menyukseskan penjelajahan anak dalam upaya mempelajari rambu-rambu lalu lintas. Salah satu pendekatan pembelajaran yang memungkinkan antara komponenkomponen pembelajaran tersebut adalah grounded theory. Grounded Theory adalah suatu pembelajaran interaktif yang mengemas sebuah metode pembelajaran berbantuan komputer yang dapat memberikan respon balik terhadap pengguna akhir (siswa) dari apa yang telah diinputkan kepada aplikasi tersebut (Murniati dan Lauaren, 2013).

Oleh karena itu pada penelitian ini melakukan perancangan aplikasi pembelajaran interaktif dengan pendekatan grounded theory berbasis android. Aplikasi ini dibuat memiliki tujuan agar siswa-siswi SD khususnya kelas II dapat mengenal rambu-rambu lalu lintas dengan metode pembelajaran tanpa harus membawa buku kemanamana, dapat dipelajari diluar sekolah, dan pengajaran mata pelajaran rambu-rambu lalu lintas menjadi lebih menarik, tidak bosen sehingga dapat memotivasi siswa-siswi untuk mempelajari ramburambu lalu lintas secara interaktif, karena aplikasi android merupakan media alternatif yang interaktif selain buku.

\section{METODE}

Dalam Membuat aplikasi ini, metode penelitian yang dilakukan berupa pengamatan interaksi langsung dengan user baik anak-anak, orang tua maupun guru. Pada penelitian ini, data dan informasi yang didapat berdasarkan pada bukubuku yang berkaitan dengan rambu-rambu lalu

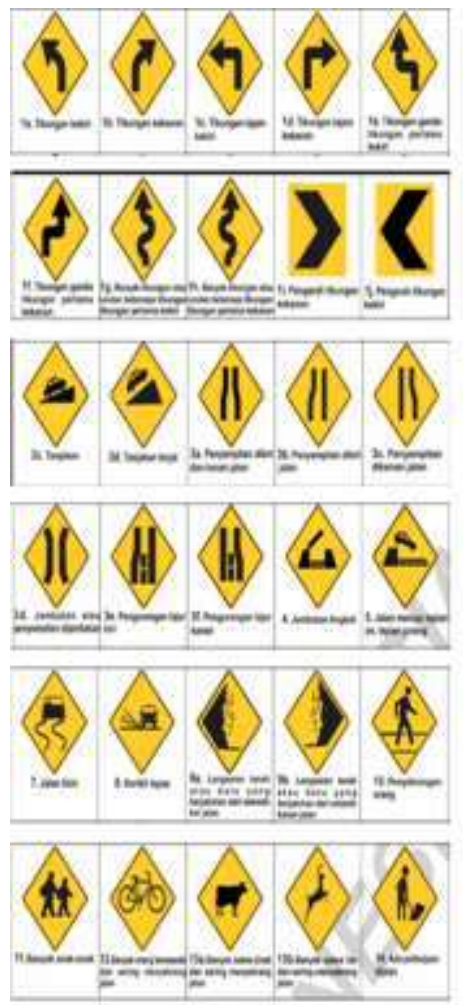

(a)
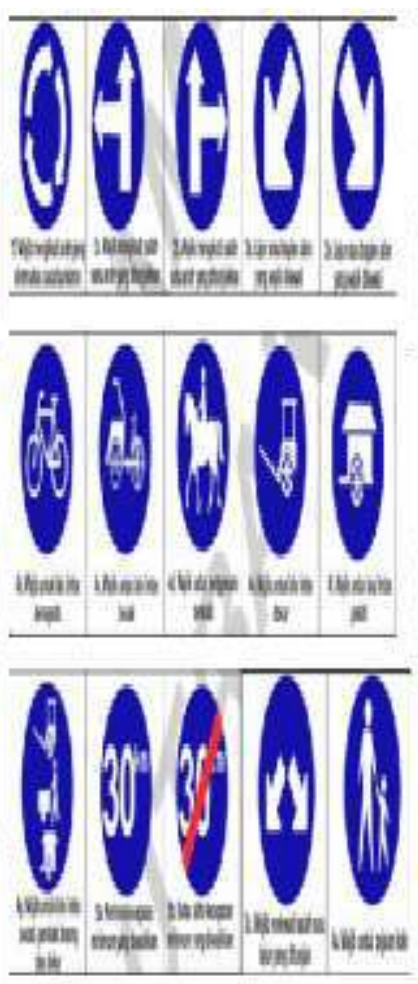

(b)
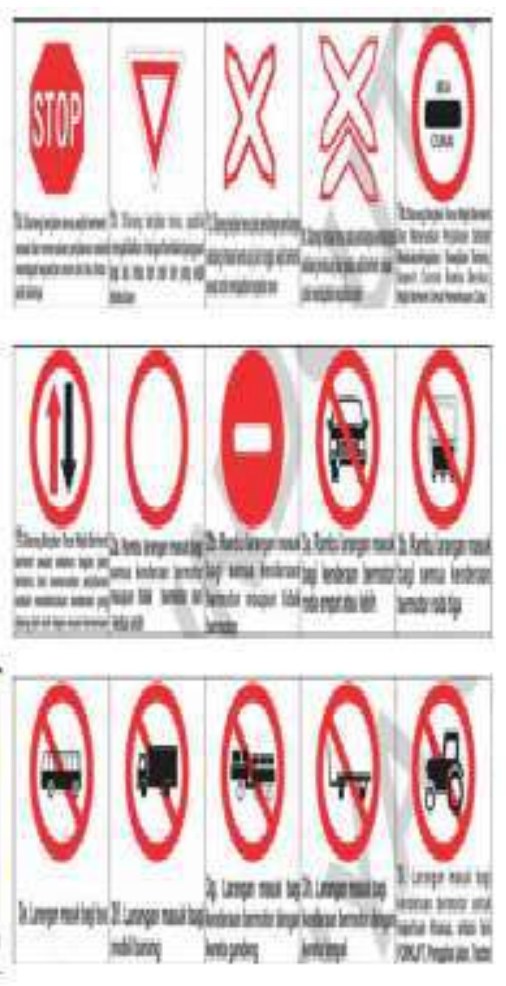

(c)

Gambar 1. Contoh Rambu-Rambu Lalu Lintas : (a) Rambu-Rambu Peringatan, (b) RambuRambu Perintah, (c) Rambu-Rambu Larangan 
lintas serta memanfaatkan jaringan internet yang tersedia. Selanjutnya dilakukan analisis data yang telah dikumpulkan untuk membuat aplikasi secara bertahap, diantaranya: perancangan system dengan menggunakan UML, perancangan interface, pengkodingan dengan menggunakan bahasa pemrograman java, dan pengimplementasian aplikasi menggunakan sistem operasi android Versi Jelly Bean 4.2.

Seiring berkembang zaman secara pesat, teknologi menjadi sesuatu yang penting untuk diikuti oleh manusia. Salah satu perangkat hasil perkembangan teknologi informasi berupa telepon genggam atau handphone dan salah satu sistem operasi yang sangat diminati saat ini adalah android. Selain perkembangan teknologi, perkembangan anak juga perlu diperhatikan, khususnya orang tua, pengajar yang lebih terampil dapat memberikan dukungan yang penting dalam membantu perkembangan anak agar berkembang lebih optimal. Selain memahami proses perkembangan individu, juga perlu memahami proses pembelajaran melalui cara belajar. Cara belajar yang interaktif, salah satunya pembelajaran dengan pendekatan grounded theory berbasis android, dimana siswa-siswi bisa belajar memahami konsepkonsep mata pelajaran tanpa harus membawa buku kemana - mana. Pada penelitian ini lebih difokuskan pada pengenalan rambu lalu lintas mengenai pengenalan lambang, huruf, angka kalimat dan atau perpaduan di antaranya, yang digunakan untuk memberikan peringatan, larangan, perintah dan petunjuk bagi pemakai jalan dilakukan dengan berbasis pada android sebagai media pembelajaran, dapat dilihat pada Gambar 1. Dengan tujuan agar dapat mengenalkan rambu-rambu lalu lintas pada siswa-siswi SD kelas II dengan pendekatan grounded theory. Pendekatan grounded theory adalah pendekatan dengan metode pengenalan konsep-konsep dasar rambu-rambu berlalu lintas. Pendekatan ini mampu menyiapkan siswa-siswi dalam membangun pengetahuan tentang lalu lintas, dan sikap positif yang akan mendatangkan manfaat saat bagi siswa-siswi sebagai generasi penerus bangsa yang berkualitas (Margono dan Purnama, 2008).

Pada penelitian-penelitian sebelumnya, media pembelajaran berbasis android telah dilakukan penilaian oleh ahli media sangat baik $(98,46 \%)$, ahli materi menilai baik $(78,46 \%)$, ahli IT menilai sangat baik $(88,89 \%)$, peer reviewer menilai sangat baik $(90,38 \%)$ dan guru SD menilai sangat baik $(89,92 \%)[8]$.

\section{Rancangan Use Case Diagram}

Diagram use case merupakan gambaran dari interaksi antara komponen-komponen suatu sistem yang akan dibangun. Pada penelitian ini,

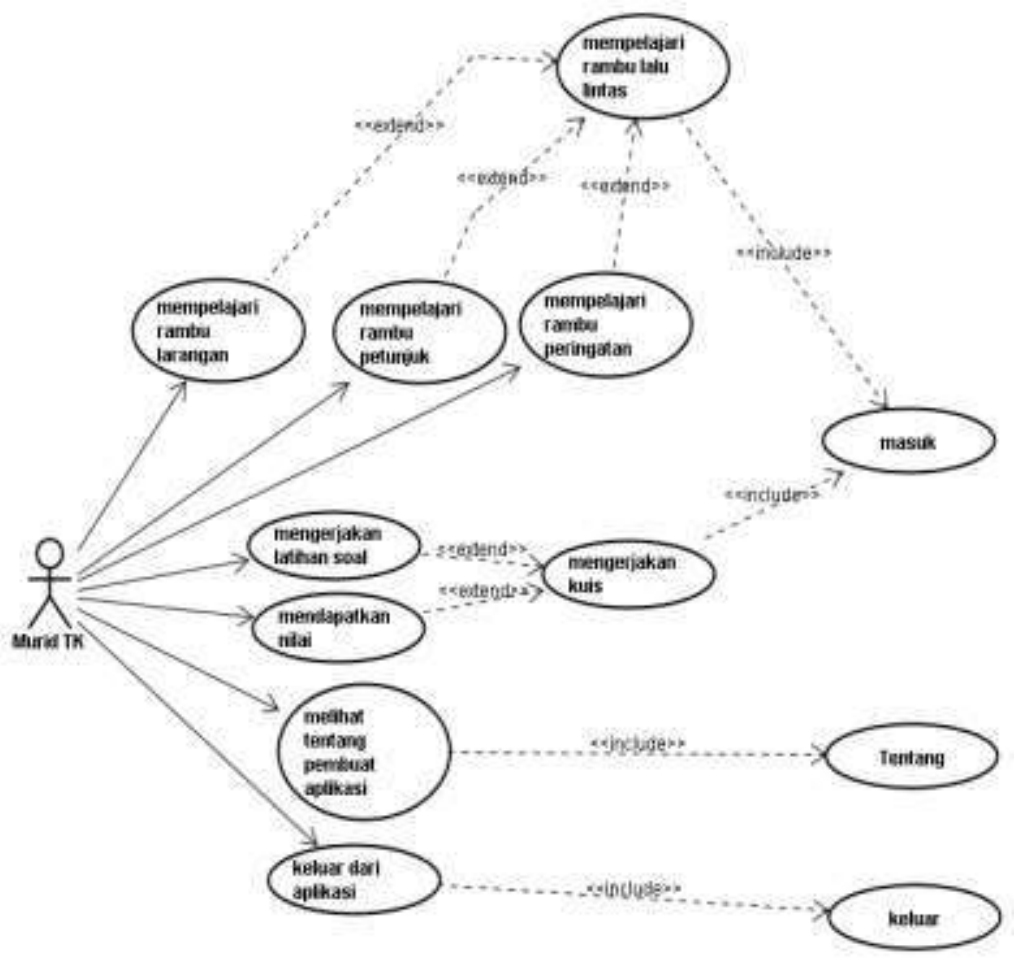

Gambar 2. Use Case Diagram Aplikasi pembelajaran rambu-rambu lalu lintas 
aplikasi pengenalan rambu-rambu lalu lintas untuk siswa-siswi SD merupakan target yang akan mempelajari jenis ramburambu lalu lintas, seperti rambu larangan, rambu peringatan dan rambu petunjuk, setelah mempelajari rambu-rambu tersebut murid bisa mengerjakan latihan soal yang telah ada, setelah mengerjakan soal latihan tersebut akan mendapatkan hasil atau nilai, kemudian murid akan mengisi nama, seperi pada Gambar 2.

\section{- Diagram Alir (Flowchart)}

Diagram Alir atau Flowchart merupakan serangkaian bagan-bagan yang menggambarkan alir program. Rancangan prosedur pada penelitian ini dapat digunakan dengan mudah oleh semua user. Yang dimaksud semua user adalah bahwa tidak hanya seorang ahli saja yang dapat menggunakan aplikasi ini, namun anak-anak maupun orang tua maupun guru dapat menggunakannya. Selain itu beberapa hal yang harus diperhatikan antara lain adalah kinerja program yang baik dalam mengoperasikan aplikasi pada penelitian ini. Aplikasi pembelajaran pada penelitian ini merupakan aplikasi modul ajar berbasis android yang mengenalkan rambu dan aturan lalu-lintas. Di lengkapi animasi yang sesuai dengan kesukaan anak-anak, sehingga mereka tidak merasa bosan untuk belajar rambu lalulintas. Adapun perancangan pembelajaran rambu- rambu lalu lintas untuk anak sekolah dasar (SD), dapat dilihat pada Gambar 3. Aplikasi pembelajaran ini dapat berjalan di platform android sehingga lebih praktis. Penggunaan media ini dalam proses pembelajaran dapat memotivasi anak dan meningkatkan pengetahuan serta keterampilan. Sehingga kesadaran keselamatan dapat ditingkatkan. Dari usia dini, sudah peduli akan tata tertib di jalan. Fasilitas yang diberikan untuk memperkenalkan dan meningkatkan kesadaran dari tata tertib lalu lintas dan terus terbawa sampai dewasa dan menularkan kedisiplinan kepada orang dewasa. Dalam dunia pendidikan suatu metode pembelajaran dapat dihadirkan dengan menggunakan alat peraga pembelajaran atau sering dikenal dengan media pembelajaran. Khususnya perkembangan teknologi di bidang pendidikan yang telah banyak memberikan sumbangan dalam memudahkan proses belajar mengajar dan memecahkan masalah belajar. Metode pembelajaran rambu-rambu lalu lintas oleh guru saat ini lebih menggunakan metode ceramah atau menggunakan alat peraga berupa gambar dan teori materi yang dilakukan di dalam kelas tidak bervariasi atau monoton, dan cara tersebut kurang efektif dan efisien dikarenakan anak kesulitan dalam membaca serta menghafal pelajaran, anak sering lupa ketika guru mereview materi pembelajaran sebelumnya dan

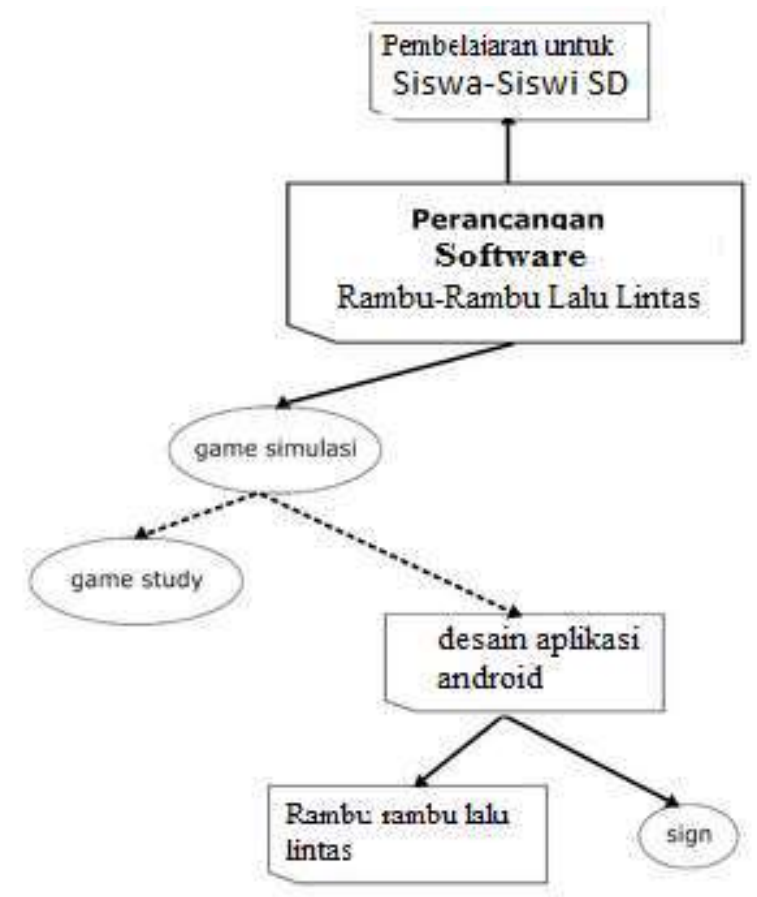

Gambar 3. Perancangan pembelajaran rambu-rambu lalu lintas untuk anak sekolah dasar (SD) 
anak cenderung tidak termotivasi saat pembelajaran dikelas dengan menunjukkan sikap acuh pada penjelasan guru, bermalasmalasan, ramai dan tidak tertib.

\section{HASIL DAN PEMBAHASAN}

Hasil penelitian dilakukan dengan menampilkan tampilan menu yang dapat diakses oleh siswa siswi $\mathrm{SD}$, dengan beberapa menu pilihan, seperti pada Gambar 4a. Pada menu utama terdapat menu masuk maka siswa-siswi dapat memilih menu untuk berbagai ramburambu lalu lintas, diantaranya rambu-rambu peringatan, larangan, perintah dan petunjuk, seperti pada Gambar 4b. Pada aplikasi menu larangan, terdapat berbagai sepuluh macam rambu larangan, diantaranya rambu stop, rambu dilarang belok kiri, dilarang belok kanan, dilarang putar balik, sepeda dilarang masuk, sepeda motor dilarang masuk, mobil dilarang masuk, sepeda motor dan mobil dilarang masuk, pejalan kaki dilarang masuk, dan bus dilarang masuk yang disertai dengan keterangannya yang bisa digunakan untuk sebagai bahan pembelajaran. Sedangkan

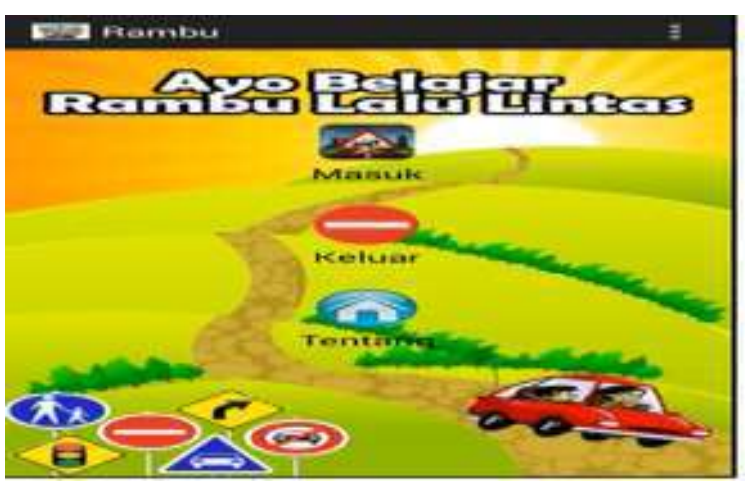

Gambar 4. (a) Tampilan Menu Utama, (b) Menu Rambu-Rambu Lalu Intas
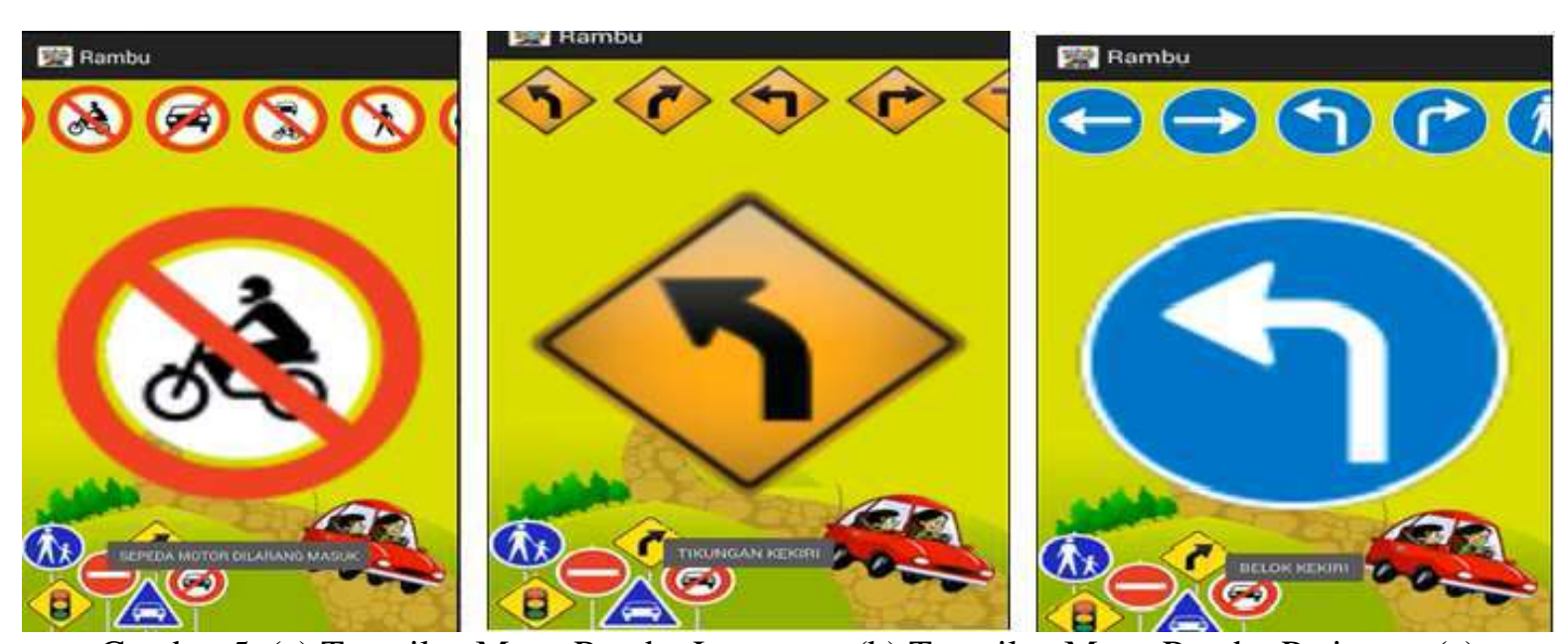

Gambar 5. (a) Tampilan Menu Rambu Larangan, (b) Tampilan Menu Rambu Peringan, (c)

Tampilan Menu Rambu Petunjuk

menu rambu peringan dan rambu petunjuk terdapat beberapa menu rambu peringatan, diantaranya adalah sepuluh gambar rambu peringatan, sepuluh gambar rambu petunjuk, pengertian dari rambu peringatandan petunjuk beserta suaranya, dapat dilihat pada Gambar 5. Pada aplikasi ini juga menampilkan menu soal latihan, dimana terdapat pilihan jenis kendaraan yang akan digunakan sebagai bahan untuk mengerjalan soal latihan yang akan dipelajari dan juga terdapat menu video untuk memunculkan tampilan beberapa gambar ramburambu yang disertai dengan videonya yang bisa digunakan untuk sebagai bahan pembelajaran, dapat dilihat pada Gambar 6 .

Rancang bangun aplikasi pembelajaran lalu lintas untuk siswa sekolah dasar berbasis android merupakan alternatif dari permainan yang disukai anak. Dengan adanya media yang disukai oleh anak, mereka dapat memahami materi yang diberikan sekaligus menyenangkan, sehingga dapat memotivasi anak dan meningkatkan pengetahuan

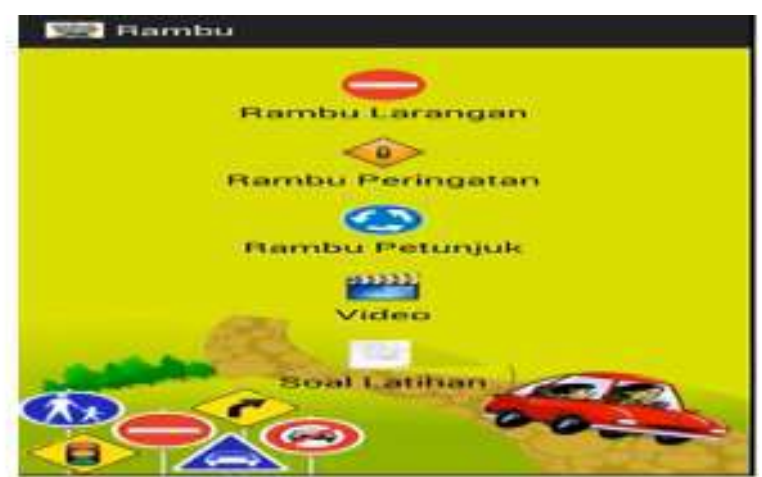



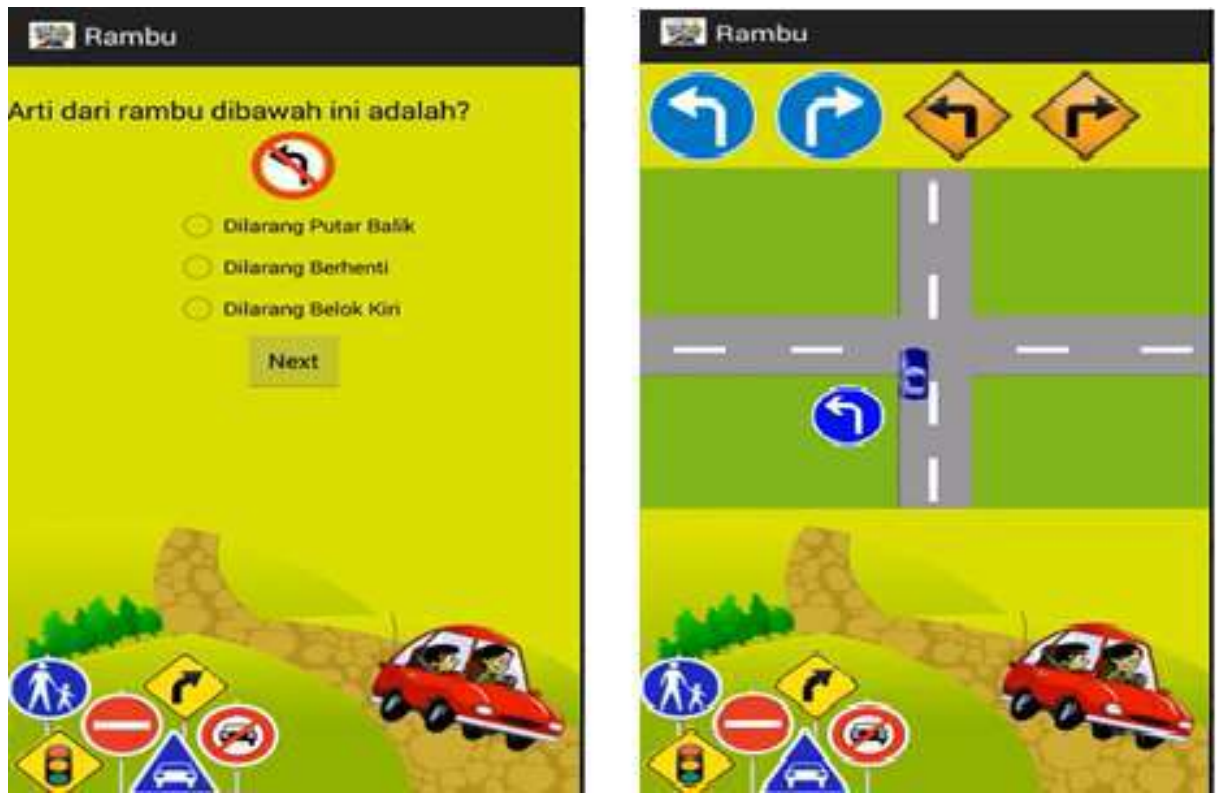

Gambar 6. (a) Tampilan Menu Latihan Soal, (b) Tampilan Menu Video

serta keterampilan dan tidak lupa pula meningkatkan kesadaran dari tata tertib lalu lintas dan terus terbawa sampai dewasa dan menularkan kedisiplinan kepada orang dewasa.

\section{KESIMPULAN}

Pada penelitian ini telah berhasil merancang dan membangun sebuah aplikasi pembelajran ramburambu lalu lintas berbasis android sehingga mampu memberikan informasi mengenai rambu-rambu lalu lintas, diantaranya peringatan, larangan, perintah dan petunjuk. Aplikasi ini juga dapat digunakan sebagai media pembelajaran karena didalamnya terdapat latihan soal mengenai rambu-rambu lalu lintas untuk memotivasi belajar siswa-siswi SD baik di sekolah maupun diluar sekolah. Selain itu, aplikasi ini juga dapat membantu sekolah menjadi SD yang berkualitas dengan menyiapkan generasi penerus bangsa yang berkualitas sadar akan hukum berlalu lintas.

\section{DAFTAR PUSTAKA}

Alisa, Marthya, 2010. Pembangunan Aplikasi Pembelajaran Panca Indera Untuk Siswa SD Berbasis Multimedia, Skripsi Program Studi Teknik Informatika Atma Jaya Universitas Atma Jaya, Yogyakarta.

Binanto, Iwan, 2010. Multimedia Digital Dasar Teori + Pengembangannya, Yogyakarta : Andi.

Ernawati, Bambang Eka Purnama. 2012. Media Pembelajaran Shalat Bagi Anak Berbasis
Multimedia, Indonesian Jurnal on Computer Scoence - Speed (IJCSS) 12 Vol 9 No 1. ISSN $1979-9330$.

Frengky.2015. Model Pembelajaran Matematika Siswa Kelas Satu Sekolah Dasar. Jurnal Psikologi. Fakultas Psikologi Universitas Gdjah Mada. Vol. 35, No. 2, Hal. 151-163.

Kusbianto, Ferry. 2013.Media Pembelajaran Microsoft Office Excel 2010 Untuk Sekolah Dasar Negeri 03 Macanan. Seminar Riset Unggulan Nasional Informatika dan Komputer FTI UNSA.

Miftahul Arif. 2014. Pengembangan Aplikasi Mobile Pembelajaran MAtematika Untuk Siswa Kelas VI SD Bebasis Android.Jurusan Teknik Informatika, Fakultas Ilmu Komputer.

Murtiwiyati dan Glenn Lauren. 2013. Rancang Bangun Aplikasi Pembelajaran Budaya Indonesia Untuk Anak Sekolah Dasar Berbasis Android. Jurnal Ilmiah KOMPUTASI, Volume 12. Nomor : 2. Hal: $1-10$.

Retno, Margono \& Purnama. 2008. Study Of Interaktif Recognition Letter and Number For Children With Computer Multimedia, Indonesian Jurnal on Computer Scoence Speed (IJCSS) 4 Volume 3 Nomor 1. ISSN $1979-9330$. 